https://doi.org/10.26593/jihi.v14i2.2963.149-162

\title{
Analisis Kekuatan Hukum dan Politik Chevron dalam Kasus Tuduhan Perusakan Lingkungan di Ekuador
}

\author{
Devita Prinanda ${ }^{1}$ \\ ${ }^{1}$ Fakultas Ilmu Sosial dan Ilmu Politik, Universitas Muhammadiyah Malang, Indonesia \\ devita.prinanda@umm.ac.id
}

\begin{abstract}
ABSTRAK
Kekuatan sebuah korporasi menjadi dilema bagi negara tempat dimana perusahaan tersebut beroperasi. Tendensi hadirnya korporasi selain mencari keuntungan juga untuk meraih kepentingan politik. Meningkatkan keuntungan merupakan aktivitas internal perusahaan, di samping itu aktivitas eksternalnya cenderung mencari kekuatan hukum. Aktivitas korporasi yang kompleks melibatkan negara dan masyarakat sebagai pengawas beroperasinya perusahaan. Apabila terjadi penyimpangan yang dilakukan korporasi maka akan ada upaya untuk menyelesaikannya melalui hukum negara penerima. Namun, kekuatan korporasi melalui tiga aspek yaitu komite aksi politik, lobi, dan kuasa hukum akan berjuang mempertahankan kerajaan bisnis dari halangan negara host. Kisah Chevron di Ekuador pada tahun 2009 hingga 2013 menjelaskan gugatan pengadilan Ekuador agar perusahaan ini mengganti rugi akibat kerusakan lingkungan di sungai dan hutan Amazon. Namun, gugatan tersebut tidak membuat korporasi asal Amerika Serikat tesebut tunduk tetapi malah melakukan gugatan balik melalui pengadilan di New York dan pengadilan intenasional. Dengan indikator kekuatan korporasi yang digagas oleh Ted Nace, penelitian ini menjelaskan upaya Chevron menghadapi politik dan hukum Ekuador dalam kasus limbah di sungai dan hutan Amazon. Penulis beragumen bahwa kekuatan Chevron untuk mempertahankan kekuasaannya di Ekuador mampu memanfaatkan hak konstitusinya untuk mendapat perlindungan atas kasus yang dihadapi di host country sehingga mampu memberikan serangan balik bagi negara yang menuntut. Hak konstitusi merupakan aspek signifikan yang menaungi perusahaan sehingga mempunyai legitimasi untuk menuntut negara.
\end{abstract}

Kata kunci: Korporasi, Chevron, Ekuador, kerusakan lingkungan, hukum, politik

\begin{abstract}
Corporate power could be a dilemma for a state where the company operates. Corporation has tendency to create wealth as well as gain political interest. Increasing profit is a natural activity of an internal firm, besides company seeks for external power such as legal strength. The complexity of corporate activities invited states and associety as a controller.If there is a deviation committed by corporation, there will be an effort to resolve it through law of the host country. However, corporation has three power to face the allegation. There are political action committee, lobbying, and attorney. Corporation will defend their business empire from any barrier from host country. The story of Chevron in Ecuador from 2009 to 2013 explained the lawsuit in Ecuadorian court. Chevron was compensated for damages due to environmental effect in Amazon river and forest. However, Chevron did not comply with Ecuadorian Judge and sued back through New York Court and International Court. Using the indicator of the power of corporation by Ted Nace, this study explains the effort of Chevron in facing Ecuadorian Politics and law. I argue that Chevron had power to maintain their grasp in Ecuador by utilizing its constitutional rights. Constitutional right is the prominent aspect of corporation to legitimate its power over state.
\end{abstract}

Keywords: Corporation, Chevron, Ecuador, Environmental Degradation, Law, Politics 


\section{Latar Belakang Masalah}

Sejarah korporasi mendapatkan legitimasi ketika banyak perusahaan Amerika melakukan akuisisi dengan membeli banyak perusahaan nasional. Kegiatan ekspansi ini didukung dengan terbentuknya General Agreement on Tariff and Trade (GATT). Bentuk perjanjian GATT yang kemudian diikuti oleh banyak perjanjian regional seperti North American Free Trade Agreement (NAFTA) merupakan bentuk kekuatan yang mendukung hak dari korporasi secara global. World Trade Organization (WTO) kemudian menjadikan bagaimana hak korporasi di bawah pemerintah satu dapat berbeda dengan negara lain dan bisa menjadi tantangan bagi negara dan perusahaan. WTO membiarkan negara dapat menuntut perusahaan dari negara lain apabila tidak sesuai dengan hukum di negara tersebut. WTO kemudian memberikan justifikasi secara global bahwa baik negara ataupun korporasi memiliki hukum yang sama di bidang perdagangan.

Hadirnya International Monetary Fund (IMF) dan Bank Dunia membawa structural adjustment program (SAP). Program ini kemudian menuntut kebijakan privatisasi bagi negara berkembang yang menerima bantuan dari institusi tersebut. Dengan ini, foreign direct investment (FDI) dan perusahaan multinasional banyak beroperasi di negara berkembang dan memperluas operasi mereka. Kekuatan perusahaan semakin besar didukung dengan program tersebut. Bagaimanapun, negara kemudian menerima kehadiran korporasi karena beberapa keuntungan yang dipaparkan dalam SAP. Korporasi memiliki legalitas hukum yang kuat karena SAP masuk dalam undang-undang di banyak negara. ${ }^{1}$

Legitimasi yang diberikan kepada perusahaan menjadikan perusahaan memiliki hak hukum yang sama dengan individu. Korporasi

${ }^{1}$ Ted Nace, Gangs of America, The Riseof Corporate Power and The Disabling of Democracy. Berkeley: Berrett-Koehler Publishers. 2003. memiliki hak hukum sebagai pondasi melakukan kegiatan bisnis. Berdasarkan hak hukum yang dimiliki dan didasari dengan kekuatan pengaruh ekonomi yang besar pada selanjutnya korporasi memiliki kekuatan politik yang berpengaruh bagi negara host.

Salah satu korporasi yang bergerak pada industri minyak bumi yaitu Chevron melakukan ekspansi perusahan ke Ekuador pada tahun 2000. Pada operasi Chevron di Ekuador, Chevron mengalami tuduhan berupa pencemaran Sungai Amazon oleh masyarakat dan pemerintah Ekuador. Chevron menganggap bahwa perusahaannya tidak melakukan kerusakan tersebut dan sudah beroperasi seusai dengan keberlanjutan lingkungan. Selain itu, Chevron mengklaim bahwa yang melakukan pencemaran pada sungai Amazon adalah perusahan Texaco yaitu perusahaan produsen minyak bumi yang diakuisisi oleh Chevron.

Texaco beroperasi di Ekuador sejak 1964. Perusahaan ini beroperasi di bidang produksi minyak. Texaco merupakan salah satu perusahaan besar di Amerika Latin. Di Ekuador, perusahaan ini mulai melakukan pengeboran terhadap sumber daya Ekuador pada 1972-1992. Setelah Texaco meninggalkan Ekuador di 1992, perusahaan ini meninggalkan 1000 pit terbuka. Di wilayah sungai Amazon, masyarakat melakukan aktivitas dengan memanfaatkan air tersebut. Kenyataan bahwa air tersebut tercemar menjadikan permasalahan sendiri bagi warga setempat. Akses air digunakan untuk mandi, masak, dan kehidupan sehari-hari. Akibat pencemaran tersebut selain penyakit kanker, kulit, gangguan saraf, dan reproduksi yang menjadikan beberapa suku seperti Tetetes dan Cofanes juga memberikan biaya besar untuk pemulihan hutan. Estimasi pemulihan bisa sampai berpuluh-puluh tahun dan memakan biaya hingga 6 miliar dolar.

Pada tahun 2000, Chevron resmi melakukan akuisisi terhadap perusahaan Texaco senilai 100 miliar dolar. Perusahaan tersebut 
kemudian menjadi Chevron Texaco Corporation. Tujuan dari kerjasama bisnis ini adalah untuk mengembangkan perusahaan minyak asal Amerika Serikat untuk memperluas wilayah operasinya. Hal tersebut dilakukan dikarenakan kepentingan pemegang saham keduanya yang menginginkan peningkatan kekuatan, efisiensi biaya produksi, peningkatan teknologi, dan sebagainya. $^{2}$

Pada tahun 2011 Ekuador menuntut Chevron dan mengajukan gugatan. Akibat kerusakan lingkungan yang terjadi di Ekuador, Pengadilan di Lago Agrio Ekuador meminta Chevron untuk membayar denda sebesar 8,6 Miliar Dolar dan bisa bertambah sesuai dengan aturan yang berlaku. Hukuman tersebut dikatakan Pengadilan di Lago Agrio sebagai ganti rugi moral karena sudah banyak penduduk yang meninggal akibat air yang tercemar dan tidak bisa terselamatkan lagi. Racun yang terkandung di dalam sungai Amazon mengandung karsinogen seperti kromium dan menyebabkan banyak yang terkena kanker. ${ }^{3}$

Sedangkan Chevron sudah memberikan tanggung jawab lingkungan saat Chevron mulai memasuki wilayah Ekuador. Dalam kasus Chevron, otoritas korporasi diuji melalui isu kerusakan lingkungan. Sehingga Chevron melakukan pembelaan di pengadilan Ekuador, pengadilan di Amerika Serikat, dan pengadilan internasional di bawah pengawasan Den Haag.

Penelitian ini mengkaji lebih dalam terkait upaya Chevron dalam proses hukum yang diajukan oleh Ekuador melalui beberapa pembelaan dan tuntutan. Melalui proses hukum tersebut, maka diharapkan penelitian ini dapat menjelaskan bagaimana kekuatan korporasi secara hukum dan politik dalam melawan

\footnotetext{
${ }^{2}$ Chevron Press Release. Chevron and Texaco Agree to $\$ 100$ Billion Merger. San Fransisco: Chevron. 2000.

${ }^{3}$ Detik (2012, 4 Januari) Chevron di Ekuador Diminta Bayar Denda.

Disandur dari https://news.detik.com/bbc-world/d1806795/chevron-di-ekuador-diminta-bayar-denda
}

gugatan negara. Apakah kekuasaan negara tetap bisa mempertahankan kedaulatan dan kepentingan nasionalnya atas beroperasinya perusahaan asing ataukah perusahaan tersebut yang memiliki kekuatan yang lebih besar dalam proses hukum dan politik.

\section{Tinjauan Pustaka}

Penelitian ini melanjutkan penelitian terdahulu yang berjudul Winning Public Trust in Multi-Actor Bargaining A Case Study of PT SMART Strategy in Facing Allegation of Environmental Destruction through RSPO. Penelitian tersebut ditulis sendiri oleh penulis untuk melihat bagaimana kemampuan perusahaan dalam melakukan tawar-menawar pada tatanan global yang baru. Kasus yang diangkat dalam penelitian tersebut yaitu kasus perusakan lingkungan yang dituduhkan kepada PT. SMART Tbk dalam kegiatan produksi minyak kelapa sawit di Indonesia. Proses tawarmenawar yang dilakukan PT. SMART Tbk untuk memulihkan citra perusahaan dilakukan dengan memenuhi karakteristik dari multi-actor bargaining. Konsep yang digunakan dalam penelitian tersebut adalah Multi-stakeholder initiative dan public trust. ${ }^{4}$

Selanjutnya penelitian tersebut dijadikan acuan untuk melihat kasus pada aktor bisnis lain dalam menangani kasus serupa yaitu lingkungan. Yang membedakan dengan penulisan sebelumnya adalah, penulis ingin melihat kekuatan korporasi dari pada proses tawarmenawar. Kerangka konseptual yang digunakan dalam penelitian ini adalah konsep tentang korporasi global, hukum perdagangan internasional, dan alat analisis menggunakan indikator kekuatan korporasi.

\footnotetext{
${ }^{4}$ Devita Prinanda dan Vinsensio Dugis, Winning Public Trust in Multi-Actor BargainingA Case Study of PT SMART Strategy in Facing Allegation of Environmental Destruction through RSPO. Atlantis Press. 2017.
} 


\section{Korporasi Global}

Konsep korporasi lebih mengarah kepada konteks ekonomi yang menekan pada pasar. Berdasarkan pemahaman teori ekonomi klasik, pasar dan segala bentuk keputusan di dalamnya dikendalikan oleh individu dan perusahaan. Aktor-aktor tersebut mengedepankan keuntungan dengan berbagai upaya yang keputusannya didasari oleh pertimbangan pasar, harga, dan faktor eksternal. ${ }^{5}$

Perilaku korporasi dalam pasar yang menekankan keuntungan yang maksimal. Berusaha untuk meminimalisir biaya produksi, menghindari pajak, meminimalkan upah buruh, mengabaikan persoalan lingkungan, dan aktivitas pendukung lainnya. Kegiatan korpoasi dilakukan dalam teritori negara yang membuat dilema negara dalam menjaga kepentingan investasi dan keamanan serta kesejahteraan.

Secara rasional, korporasi melakukan kegiatan operasional dengan memprioritaskan opportunity cost. Keputusan dalam bisnis hanya menjawab tentang untung dan rugi. Tidak ada permasalahan moral, lingkungan, dan sebagainya. Hal tersebut yang mendukung terjadinya kejahatan korporasi di dalam batas teritori negara. ${ }^{6}$ Di sisi lain, negara memiliki wewenang untuk mengatur sistem ekonomi nasional. Namun, pada prakteknya, aktivitas korporasi berkembang pesat dan memiliki keuntungan yang lebih besar.

Berkembangnya korporasi membentuk konsep kekuatan yang dimiliki oleh aktor tersebut. Kekuatan korporasi yang pertama adalah dapat melakukan kontrol terhadap aset negara. Kedua, dasar kegiatan ekonomi (produksi, distribusi, dan konsumsi), korporasi memiliki peran yang signifikan. Ketiga, korporasi berperan besar kepada ekonomi dan

5 Robert Gilpin, Global Political Economy. New Jersey: Princeton University Press. 2001.

6 Arief Amrullah, Perkembangan Kejahatan Korporasi. Jakarta: Rajawali Pers. 2018. pertumbuhan global. Korporasi mendukung adanya perkembangan teknologi dan inovasi yang berdampak positif pada sektor industri dan berpengaruh pada pertumbuhan ekonomi negara.

Di samping itu, dalam kajian negara dan pasar, negara memiiki peran khusus dalam hubungannya dengan korporasi. Pertama, aturan di tingkat multilateral mengenai perdagangan internasional diselenggarakan dan diratifikasi oleh aktor negara. Ketetapan global tersebut kemudian dijadikan dasar bagaimana korporasi bertindak. Kedua, korporasi memerlukan negara untuk melegitimasi aktivitas bisnisnya. Dukungan dari negara berupa ijin, akses terhadap sumber daya, indrastruktur, dan aspek lainnya merupakan kebutuhan sebuah korporasi yang didapat dari negara. Hal ini membuar korporasi harus melakukan lobi dengan pemerintah domestik untuk mendapatkan keputusan yang menguntungkan. Terakhir, negara memiliki kemampuan untuk mengatur kompetisi asing melalui kebijakan entry barriers. Korporasi memerlukan peran negara agar terhindar dari foreign supplier yang merupakan kompetitor. ${ }^{7}$

Dalam penelitian ini korporasi global digunakan untuk menjelaskan bagaimana aktivitas Chevron di Ekuador dengan konteks negara dan pasar. Chevron merupakan korporasi global asal Amerika Serikat yang memiliki kekuatan dalam kegiatan produksi dan distribusi minyak bumi. Sedangkan Ekuador merupakan aktor negara yang memiliki kekuasaan untuk menjaga dan melindungi negara dan rakyatnya dari aktivitas korporasi yang hanya mengedepankan profit.

\section{Hukum Perdagangan Internasional}

Transaksi yang dilakukan dalam perdagangan merupakan kebebasan fundamental

\footnotetext{
7 Dewi Senorita Setepu dan Silvia Dian Aggraini, Fenomena Korporasi dalam Konstelasi Internasional - Tinjauan Teoritis (pp. 83-107). Global \& Strategi.. 2007.
} 
dimana kebebasan berdagang tidak terbatasi oleh perbedaan-perbedaan seperti agama, suku, ras, politik, dan lain-lain. Hal ini menjadikan dasar bahwa setiap negara berhak melakukan perdagangan internasional. ${ }^{8}$

Hukum perdagangan sendiri menurut Schmitthoff adalah aturan yang mengatur hubungan komersial yang didasari oleh bentuk transaksi. Hukum perdagangan internasional yang berlaku adalah yang disepakati secara internasional melalui GATT (General Agreement on Tariff and Trade) ataupun kesepakatan di tingkat regional. Dalam kesepakatannya mencakup aturan, prinsip, dan norma. Hal ini dapat dikatakan sebagai regulatory regime.

Hukum perdagangan internasional terbagi menjadi public international trade law dan private international trade law. Public international trade low adalah hukum publik yang mengarah kepada perdagangan antar negara. Sedangkan private international trade law mengatur hubungan dagang antara individu dan perusahaan. Pada implementasinya, antara hukum publik dan privat sulit untuk dibatasi karena pada praktiknya yang sering tumpangtindih.

Aleksander Goldstajn mengemukakan tiga prinsip dasar hukum perdagangan internasional. Pertama, prinsip dasar kebebasan melakukan kontrak. Prinsip ini menjelaskan keleluasaan untuk menyepakati kontrak perdagangan. Kedua, prinsip pacta sunt servanda. Prinsip ini menjelaskan bahwa pihakpihak dalam kontrak perdagangan harus menghormati dan melaksanakan kontrak dengan sebaik-baiknya. Ketiga, prinsip dasar penyelesaian sengketa melalui arbitrase. Prinsip ini mengkerangkai penyelesaian sengketa

${ }^{8}$ Emmy Latifah. Eksistensi Prinsip-prinsip Keadilan dalam Sistem Hukum Perdagangan Internasional (pp. 64-86). Padjajaran Jurnal Ilmu Hukum. 2015. dagang melalui jalur hukum. Terutama ketika terdapat kontrak-kontrak yang dilanggar. ${ }^{9}$

Pada penelitian ini, hukum perdagangan internasional digunakan untuk menjelaskan bagaimana upaya hukum yang ditempuh Chevron dalam menghadapi Ekuador. Lembaga hukum nasional dan internasional terlibat dalam perseteruan dan kegiatan tersebut melibatkan aturan-aturan perdagangan internasional.

\section{Kekuatan Korporasi}

Setiap perusahaan multinasional beroperasi di negara lain maka akan diikuti oleh hukum yang berlaku dan beberapa isu. Isu-isu fundamental dalam operasional perusahaan multinasional antara lain lingkungan, hak asasi manusia, kesetaraan dan sosial. Selain perusahaan harus berhadapan dengan hukum di negara tempat ia beroperasi, mereka juga harus berhadapan dengan standar-standar serta hukum adat yang diberlakukan oleh masyarakat. Perusahaan multinasional tidak hanya berhadapan dengan negara dan regulasi tapi juga berhadapan dengan organisasi non-pemerintah dan kelompok kepentingan lainnya di negara tujuan. $^{10}$

Korporasi memiliki kekuatan politik dan hukum. Kekuatan bisa meliputi pengaruh terhadap kebijakan dan politik suatu negara. Ted Nace menjelaskan survei dari business weeks pada tahun 2000 menyatakan bahwa kekuatan korporasi berasal dari komite aksi politik, kemampuan bernegosiasi, kuasa hukum perusahaan, dan kemampuan mereka dalam mengontrol lapangan pekerjaan. Untuk memperkuat pengaruh politik, perusahaan juga dapat melakukan kontrol terhadap media. Hal tersebut yang membuat Nace memaparkan bukunya tentang bagaimana korporasi bisa

\footnotetext{
9 Adolf, Huala. Hukum Perdagangan Internasional. Jakarta: Rajawali Pers. 2009.

${ }^{10}$ Don Mayerdan Ruth Jebe. The Legal and Ethical Environment for Multinational Corporations. Good Business (Routledge, 2010).
} 
mendapatkan kekuatan, mengapa negara takut dengan perusahaan multinasional, dan bagaimana korporasi bisa mendapatkan hak-hak hukum. ${ }^{11}$

Ted Nace juga melakukan personifikasi terhadap korporasi. Seperti halnya manusia, korporasi memiliki hak-hak seperti proteksi, hak hukum dan proses hukum terkait kriminal, hakhak politik, dan sebagainya. Implikasi dari personifikasi pada institusi bisnis adalah konsekuensi kepada polarisasi kekayaan yang diciptakan dam ketidakmampuan negara untuk mengatasi kekuatan perusahaan.

Penyebab korporasi memiliki kekuatan untuk mempengaruhi aktivitas politik adalah mereka memiliki hak konstitusi. Korporasi memiliki kemampuan melobi, kampanye di masyarakat, dan mengoperasikan perusahaannya di luar negeri. Kekuatan politik perusahaan melalui proses lobbying. Proses melobi yang dilakukan perusahaan di negara host bertujuan untuk mendapatkan pengaruh dari pihak eksternal. ${ }^{12}$ Hak konsitusional perusahaan dapat diartikan sebagai kekuatan politik. Hak konstitusional bisa membuat perusahaan menantang undang-undang dan hukum karena haknya atas kepemilikan kuasa hukum.

Sebagai subjek hukum, perusahaan bisa dikatakan sebagai manusia karena memiliki hak yang setara di bawah yurisdiksi. Ted Nace nengatakan bahwa korporasi memiliki quasi rights yang kuat bukan memiliki hak konstitusi yang dikatakan sebelumnya. Kedua, perusahaan memiliki sebelas hak konsitusi dari serangkaian keputusan mahkamah agung. Ketiga, korporasi dapat mengesampingkan otoritas negara yang berdaulat. Korporasi mendapatkan serangkaian hak tersebut melalui sejarah panjang. Adapun indikator dari masing-masing hak yang dimiliki oleh perusahaan adalah sebagai berikut:

\footnotetext{
${ }^{11}$ Nace, Ted, op. cit.

${ }^{12}$ Christoph Dörrenbächer \& Mike Geppert. Politics and Power in the Multinational Corporation (Cambridge University, 2011)
} 
Tabel 1. Tabel Perkembangan Hak Korporasi menurut Ted Nace

\begin{tabular}{|c|c|c|}
\hline Quasi Rights & Constitutional Rights & Global Rights \\
\hline $\begin{array}{ll}\text { Limited Liability } & \text { for } \\
\text { shareholders } & \end{array}$ & Equal Protection & $\begin{array}{lll}\text { Minimum } & \text { standard } & \text { of } \\
\text { treatment } & & \end{array}$ \\
\hline Perpetual existence & $\begin{array}{l}\text { Due Process } \quad \text { (State } \\
\text { Legislation) }\end{array}$ & National treatment \\
\hline Virtual location & $\begin{array}{l}\text { Due Process } \quad \text { Federal } \\
\text { Legislation) }\end{array}$ & $\begin{array}{l}\text { Compensation for regulatory } \\
\text { takings }\end{array}$ \\
\hline $\begin{array}{l}\text { Indefinite entity or "shape } \\
\text { shifting" }\end{array}$ & $\begin{array}{l}\text { Freedom from unreasonable } \\
\text { searches }\end{array}$ & \\
\hline \multirow[t]{7}{*}{ Protection from law suites } & Jury trial in a criminal case & \\
\hline & $\begin{array}{l}\text { Compensation for government } \\
\text { takings }\end{array}$ & \\
\hline & $\begin{array}{l}\text { Freedom from double } \\
\text { jeopardy }\end{array}$ & \\
\hline & Jury trial in a civil case & \\
\hline & Commercial Speech & \\
\hline & Political Speech & \\
\hline & Negative Speech & \\
\hline
\end{tabular}

Korporasi diklasifikasikan ke dalam dua versi yaitu classic corporation dan modern corporation. Classic corporation adalah korporasi pada era sebelum 1860 dimana korporasi ditentukan batas operasinya oleh negara. Kegiatannya ditentukan oleh home country dimana aktivitas dan fugsi-fungsi perusahaan memiliki batasan tertentu. Korporasi dibatasi waktunya untuk beroperasi kurang lebih 20-30 tahun. Sedangkan modern corporation adalah korporasi yang beroperasi di atas tahun 1900 dan memiliki sedikit batasan dibandingkan classic corporation. Modern corporation memiliki kewenangan untuk mengembangkan bisnis dan tidak memiliki batasan waktu untuk beroperasi.

Secara universal, korporasi mendapatkan hak konstitusi pertama kali pada 1866. Namun, di Inggris status hukum korporasi sudah ada sejak 1819. Di tahun 1900, Hakim Amerika Serikat memutuskan korporasi memiliki hak untuk mengajukan keberatan kepada badan legislatif. ${ }^{13}$

Dalam kasus lingkungan, ketika korporasi mendapatkan persoalan yang dibawa dalam pengadilan maka mereka dapat mempertahankan perusahaannya. Pada pembahasan akan dijelaskan bagaimana Chevron melakukan

\footnotetext{
${ }^{13}$ Nace, Ted, op.cit.
} 
proses lobbying dan kampanye sebagai strategi politik untuk mengatasi tuduhan dan mempertahankan perusahaan. Sedangkan secara hukum, Chevron melakukan perlawanan melalui badan hukum untuk memenangkan gugatan yang dilakukan oleh Ekuador.

\section{Metode Penelitian}

Pendekatan penelitian ini adalah kualitatif dengan jenis penelitian Content Analysis. Penelitian ini berusaha untuk memberikan gambaran secara menyeluruh mengenai tinjauan politik dan hukum dalam memandang fenomena kekuatan korporasi yaitu Chevron dalam menghadapi gugatan Ekuador.

Teknik pengumpulan data yang digunakan dalam penelitian ini adalah dokumentasi. Dimana dalam teknik pengumpulan ini adalah data sekunder. Dimana sumber daya tersebut memiliki keterkaitan dengan tema kekuatan korporasi dalam tuduhan lingkungan, yang diperoleh melalui literatur cetak maupun elektronik yang berupa dokumen lembaga, buku, artikel, majalah, jurnal, koran, serta laporan dari sumber yang kredibel.

Teknik analisa data yang digunakan adalah teknik analisa deduktif, dimana data-data diperoleh melalui dalil umum, postulat, dan paradigma tertentu yang kemudian dihubungkan dengan data-data empiris yang menjadi titik pengambilan kesimpulan dari data tersebut. Beberapa data yang berkenaan dengan angka, akan diterjemahkan ke dalam bentuk verbal. Penelitian kualitatif dalam studi llmu Hubungan Internasional adalah melakukan pengumpulan data dan melakukan analisis pada data nonnumerik. Dalam penelitian ini metode yang digunakan adalah content analysis. ${ }^{14}$

Dalam penelitian ini, data-data yang berkaitan dengan variabel dalam kekuatan hukum dan politik korporasi direduksi dan

14 Bakry, Umar Suryadi. Metode Penelitian Hubungan Internasional. Yogyakarta: Pustaka Pelajar, 2017. dipilah kembali untuk dicari kesesuaian dengan kebutuhan data sebagai pendukung untuk menjawab pertanyaan penelitian terkait dengan kekuatan korporasi dalam kasus tuduhan Ekuador terhadap Chevron.

\section{Pembahasan}

Ekuador memiliki sumber daya minyak bumi yang besar. Sehingga operasi Texaco menjadi perhatian bagi pemerintah Ekuador. Namun pada era Texaco beroperasi, perusahaan ini bukan perusahan dominan di Ekuador. Petroecuador merupakan perusahaan negara yang menguasai produksi negara tersebut. Namun, untuk komoditas ekspor di wilayah Amerika Latin, Texaco yang memegang kuasa. Texaco dan Petroecuador menjalankan kerjasama, namun lebih banyak keputusan dikuasai oleh perusahaan nasional. Petroecuador mendominasi akibat maraknya kebijakan nasionalisasi di negara-negara Amerika Latin. Dengan ini, Texaco menjadikan Texpet salah satu cabang perusahaan untuk bekerjasama dengan Petroecuador. ${ }^{15}$

Perjanjian antara Texaco dan Petroecuador diatur oleh pemerintah Ecuador. Pemerintah yang menentukan harga minyak yang diproduksi oleh Texaco. Texaco tidak bisa menjual minyak untuk keuntungan perusahaan selain dengan ijin pemerintah. Perjanjian ini disepakati pada tahun 1973 hingga 1992. Tujuannya adalah agar kebutuhan nasional Ekuador bisa dipenuhi dengan adanya investasi dari perusahaan dari Amerika Serikat tersebut. Di tahun 1992, Texaco tidak ingin memperpanjang perjanjian tersebut sehingga Texaco memberhentikan operasinya di Ekuador. ${ }^{16}$

15 Black, Elizabeth C. "Litigation As A Tool For Development: The Environment, Human Right, and The Case of Texaco in Ecuador," Journal of Public and International Affairs 15, 142-164. (2004)

16 Ejolt. The Texaco-Chevron Case in Ecuador. s.1.:Environmental Justice Organisations, Liabilities, and Trade. (2015). 
Pada tahun 1993 komunitas Amazon mengklaim bahwa daerah mereka mengalami kerusakan sejak beroperasinya perusahaan minyak Texaco. Kerusakan itu terjadi pada kurun waktu 1964 dan 1990. Texaco melakukan pembuangan gas beracun ke dalam sungai amazon dengan jumlah miliaran galon. Dampak dari tercemarnya sungai Amazon adalah gagal panen, menurunnya tingkat kesehatan masyarakat di sekitar Amazon akibat kasus kanker, dan banyaknya hewan yang mati. Masyarakat yang melaporkan kepada lembaga swadaya masyarakat setempat yang kemudian dilanjutkan pada pengadilan.

Secara detail, Texaco memiliki metode pengeboran yang merusak lingkungan dan kesehatan. Prosedur yang dimiliki Texaco sangat jauh dari keamanan lingkungan. Hal ini dikarenakan Texaco menggunakan metode yang murah dan berpolusi. Limbah yang dibuang Texaco ke Sungai Amazon mengandung unsur kimia seperti benzen, arsenik, air raksa, dan zat berbahaya lainnya. Untuk membayar kerusakan dan kerugian tersebut, Texaco mengadakan perjanjian dengan pemerintah untuk mengganti rugi sejumlah 40 juta dolar. ${ }^{17}$ Perjanjian antara Texaco dan Ekuador terkait penemuhan tanggung jawab lingkungan ditandatangani pada tahun 1995. Dan pada 1998, Texaco telah menyelesaikan perbaikan lingkungan. ${ }^{18}$ Program tersebut mengoperasikan perkongsian atas hasil audit yang dilakukan antara pemerintah Ekuador dan pihak Texaco. Sehingga kemudian muncul kesepakatan tanggung jawab lingkungan sesuai hasil perjanjian. ${ }^{19}$

Namun, di tahun 2011 Ekuador tetap menuntut Chevron dan mengajukan gugatan.

\footnotetext{
${ }^{17}$ Black, Elizabeth C. op. cit.

${ }^{18}$ Prigau. The Texaco-Chevron case in Ecuador: Law and justice in the age of Globalization. RCDA. Vol 5. No. 1. (2014)

19 Chevron. Texaco Petrolium, Ecuador, and The Lawsuit Against Chevron. (San Ramon: Chevron Corporation, 2011)
}

Akibat kerusakan lingkungan yang terjadi di Ekuador, Pengadilan di Lago Agrio Ekuador meminta Chevron untuk membayar denda sebesar 8,6 miliar dolar dan bisa bertambah sesuai dengan aturan yang berlaku. Hukuman tersebut dikatakan Pengadilan di Lago Agrio sebagai ganti rugi moral karena sudah banyak penduduk yang meninggal akibat air yang tercemar dan tidak bisa terselamatkan lagi. Racun yang terkandung di dalam sungai Amazon mengandung karsinogen seperti kromium dan menyebabkan banyak yang terkena kanker. (Detik News, 2012).

Chevron menyatakan tidak terima dengan gugatan Pengadilan Negeri Ekuador. Perusahaan ini mengklaim beberapa pembelaan atas perusahaannya dan tidak mengakui konstitusi Ekuador terkait kasus ini. Pembelaan pertama, Chevron tidak seharusnya bertanggungjawab atas kegiatan Texaco di tahun sebelum Chevron melakukan akuisisi, kedua, Texaco telah menyelesaikan perbaikan lingkungan yang disepakati tahun 1998. Ketiga, operasional terbesar di masa Texaco adalah Petroecuador yang seharusnya memberikan kontribusi pencemaran lingkungan yang lebih besar. Keempat, bahwa bukti yang diajukan masyarakat Ekuador terhadap Chevron tidak sah dan banyak dilakukan manipulasi secara sains. Di samping itu, Chevron juga mengumumkan adanya kasus suap terhadap hakim agar Chevron membayarkan ganti rugi. Chevron mengunggah video secara online untuk membuktikan adanya ketimpangan birokrasi di balik kasus yang melibatkan Chevron. ${ }^{20}$ Selanjutnya, Chevron melakukan banding atas keputusan Pengadilan Ekuador. Banding dilakukan dengan serangkaian alasan yang telah disebutkan sebelumnya. Kecurangan dalam proses peradilan yang

\footnotetext{
20 Detik Finance (2011, 15 Februari) Cemari Lingkungan, Chevron Didenda Rp 72 Triliun.

Disandur dari https://finance.detik.com/energi/d1571377/cemari-lingkungan-chevron-didenda-rp-72triliun
} 
diwarnai dengan tindakan korupsi dijadikan sebagai landasan kuat untuk mengajukan banding. ${ }^{21}$

Di sisi lain, Chevron merasa sudah memberikan kontribusi untuk keselamatan lingkungan di sekitar Amazon pada 1990an melalui perusahaan pendahulunya yaitu Texaco. Pada waktu tersebut dana sebesar 40 juta dolar digunakan untuk membersihkan area Amazon. Kemudian antara Chevron ( Texaco) dan Pemerintah Ekuador sudah sepakat pada tahun 1998 bahwa Chevron bebas dari tanggungan terkait lingkungan ke depannya. ${ }^{22}$

Texaco ataupun Chevron bukanlah penyumbang utama perusakan lingkungan di wilayah tersebut. Operasi Petroecuador memiliki kontribusi besar terkait dengan limbah yang dihasilkan. Pemerintah Ekuador dianggap mengalihkan tuduhan terhadap perusahaan milik negara dengan tidak memberikan bukti bahwa Petroecuador gagal memberikan perhatian pada sanitasi dan kesehatan. ${ }^{23}$

Untuk membuat legitimasi bahwa Chevron tidak terbukti mengabaikan lingkungan, perusahaan tersebut mengambil 1472 sampel air dan tanah dari 45 area berbeda untuk diuji di World Health Organization (WHO) dan laboratorium terakreditasi di Amerika Serikat seperti US Environmental Protection Agency (USEPA). Hasil uji laboratorium membuktikan bahwa 98\% Texaco atau Chevron tidak memberikan dampak signifikan terhadap lingkungan dan gangguan kesehatan. Pada tahun 2008, tim investigasi dari hakim menghasilkan

${ }^{21}$ BBC Indonesia (2011, 13 Maret). Chevron Banding Putusan Denda US\$9,5 Miliar. Disandur dari https://www.bbc.com/indonesia/dunia/2011/03/11031 3_chevronecuador

22- BBC Indonesia (2012, 4 Januari). Chevron di Ekuador Diminta Bayar Denda. Disandur dari https://www.bbc.com/indonesia/dunia/2012/01/12010 4_ekuadorchevron

${ }^{23}$ Chevron. Texaco Petrolium, Ecuador, and The Lawsuit Against Chevron. (San Ramon: Chevron Corporation, 2011) laporan bahwa $80 \%$ sudah dibersihkan dari kontaminasi dari $44 \%$ sampel air yang diambil. ${ }^{24}$ Selain itu terdapat video yang sengaja diunggah Chevron untuk membuktikan bahwa terdapat area yang tidak terkontaminasi limbah. Video tersebut memaparkan beberapa pegawai Chevron meninjau keadaan di sekitar sungai Amazon. Dalam video tersebut juga terdapat wawancara pegawai Chevron dengan masyarakat yang tinggal di sekitar sungai tersebut. Dikatakan oleh warga bahwa memang terdapat perusahaan minyak asal Amerika yang melakukan perusakan sekitar 20 tahun yang lalu hingga menyebabkan sapi-sapi mati. Namun, salah satu warga mengatakan perusahaan tersebut sudah membersihkan dan bertanggung jawab atas limbah tersebut. Chevron juga melakukan semacam penjelasan kontra terhadap tokoh masyarakat yang menuntut Chevron dengan menunjukkan bahwa perusahaan tersebut tidak bersalah. Video rahasia ini digunakan Chevron untuk mengelak dari pembayaran terhadap Ekuador. ${ }^{25}$

Chevron melakukan gugatan terhadap pengadilan internasional dan Pengadilan Amerika Serikat agar tidak membayarkan denda yang dituntut Pengadilan Ekuador. Chevron menganggap tuntutan Pengadilan di Lago Agrio merupakan bentuk politisasi. Hasil dari pengadilan Amerika Serikat adalah membatalkan keputusan Pengadilan Ekuador terkait dengan pembayaran denda.

Chevron melakukan gugatan melalui pengadilan di New York. Penolakan Chevron terhadap pembayaran ganti rugi ditekankan dalam pengajuan banding melalui pengadilan di

\footnotetext{
${ }^{24}$ Prigau, op. cit.

${ }^{25}$ Amazon Watch (2015, 8 April) Chevron's Secret Videos Show Company Technicians Finding and Mocking Extensive Oil Contamination in Ecuador Rainforest. Disandur dari https://amazonwatch.org/news/2015/0408-chevronssecret-videos-show-company-technicians-findingand-mocking-extensive-oil-contamination
} 
negara asal perusahaan. Mereka menolak gugatan aktivis lingkungan Amazon karena tidak memiliki aset di Ekuador dengan jumlah banyak sehingga tidak dapat membayar. Selain itu, perjanjian tidak ada lagi tanggung jawab di masa mendatang yang sudah disepakati oleh Texpet dan Ekuador merupakan bukti kuat agar tidak perlu lagi mempertanggungjawabkan kerusakan yang dituduhkan pada Texaco. ${ }^{26}$

Pada tahun 2010, pengadilan di New York mengabulkan untuk Chevron agar mendapatkan perlindungan hukum internasional. Sedangkan pada tahun 2011, Chevron mengajukan pengaduan ke Den Haag atas pelanggaran regulasi dari Perserikatan Bangsabangsa (PBB) tentang pelanggaran terhadap kegiatan investasi. Pada tahun 2012, Chevron mengajukan pembebasan bersyarat namun ditolak oleh Pengadilan Ekuador.

Chevron melihat probabilitas besar bahwa Pemerintah Ekuador memeras uang dari perusahaan asing untuk membayar sejumlah hutang luar negeri. Di samping korupsi, melalui gugatan ini pemerintah juga melibatkan masyarakat agar Petroecuador bebas dari tanggung jawab lingkungan. Ekuador melakukan penyimpangan hukum dengan melakukan korupsi dan terdapat kepentingan politik yang bisa menguntungkan beberapa pihak seperti pemerintah dan tokoh masyarakat.

Analisa penyebab bagaimana perusahaan mampu memberikan bargaining yang lebih kuat dibandingkan negara disebabkan oleh beberapa hal. Di satu sisi, negara memiliki kelemahan birokrasi dan undang-undang dan di sisi lain korporasi memiliki kekuatan yang tidak dimiliki oleh negara untuk mempertahankan eksistensinya. Baik negara dan korporasi memiliki kekuatan untuk memperkuat kepentingannya. Analisa penulisan ini akan memaparkan dilema masyarakat apakah harus mempercayai perusahaan atau negara dalam kasus Chevron dan Ekuador.

${ }^{26}$ Ejolt, op. cit.
Kelemahan dari negara host tersebut, kemudian menjadikan korporasi memiliki kemampuan untuk memberikan pengaruh secara politik. Dalam kasus ini, Chevron melakukan lobi melalui bukti-bukti hasil uji laboratorium di tingkat organisasi internasional. Chevron juga melakukan kampanye untuk membela perusahaannya melalui video yag diunggah seperti yang dijelaskan sebelumnya.

Ekuador sebagai negara yang dirugikan akibat masuknya perusahaan minyak yang melakukan eksploitasi untuk sumber daya minyak bumi di negara tersebut. Ditambah lagi, Ekuador harus mendapatkan kerugian lingkungan akibat pengolahan sumber daya alam tersebut. Ekuador memiliki yurisdiksi yang kuat untuk menghukum korporasi yang berada di wilayahnya. Menurut Nace dalam bukunya Gangs of America The Rise of Corporate Power and The Disabling of Democracy yang diterbitkan pada tahun 2003 menjelaskan sejarah hukum mengenai perusahaan multinasional kembali pada kebijakan domestik masingmasing negara. Institusi global hanya memberikan pernyataan umum bahwa operasi perusahaan memiliki hak untuk beroperasi di luar batas negara.

Texaco menawarkan kemampuan untuk mengakses sumber daya dengan teknologi yang dimiliki. Sempat terjadi nasionalisasi di wilayah Amerika Latin sehingga Texpet menjadi terdominasi oleh Petroecuador. Namun, Texaco tetap menjadi perusahaan multinasional yang berbadan hukum. Chevron masuk di 2011 sebagai korporasi dari Amerika Serikat menggantikan Texpet. Serangkaian gugatan sejak 1993 yang dilayangkan kepada Texpet kembali menjadi isu di tahun 2011 ketika Chevron memegang kendali.

Chevron merupakan salah satu perusahaan besar di pengelolaan minyak bumi. Ketika memasuki wilayah Ekuador, terindikasi bahwa negara tersebut ingin mendapatkan keuntungan besar dari masuknya perusahaan 
tersebut. Sehingga melalui isu lingkungan, Ekuador meminta imbalan berupa dana untuk perbaikan. Negara memiliki kekuatan untuk memberikan regulasi terhadap perusahaan di negara tersebut. Melalui kekuatan hukum yang dimiliki tuntutan tersebut diberikan kepada Chevron. Kembali pada konsep negara sebagai aktor yang berdaulat sebagai insitusi yang memiliki otoritas penuh atas teritorinya. Perkembangan konsep kedaulatan mengikuti tatanan dunia baru yang memiliki pergeseran. Globalisasi menghadirkan pergeseran makna pada kedaulatan dengan kekuatan aktor nonnegara pada tatanan global. ${ }^{27}$

Bukan merupakan hal baru jika beroperasinya perusahaan multinasional akan memberikan kerugian pada negara host. Kerugian bisa merupakan eksploitasi sumber daya alam, perusakan lingkungan, ataupun penyebab konflik sosial dengan masyarakat. Dalah hal ini, Texpet telah menyebabkan kerusakan lingkungan dan menyebabkan kematian pada banyak warga di beberapa suku di wilayah Oriente. Sehingga terjadi protes oleh kelompok masyarakat lokal akibat pencemaran air yang merugikan kesehatan. Yang dilupakan oleh korporasi adalah, mereka beroperasi di wilayah hukum negara lain, sehingga harus mempertanggung jawabkan kesalahannya sesuai dengan hukum yang berlaku. Perusahaan juga mengesampingkan kekuatan masyarakat untuk mendorong negara melakukan tuntutan.

Di samping itu, negara melupakan bahwa korporasi juga memiliki sejumlah kekuatan seperti yang dijelaskan oleh Ted Nace. Chevron juga memiliki quasi rights dan kemampuan melobi hukum dan politik. Chevron memiliki hak konstitusi untuk mengajukan banding dan menahan untuk tidak membayar denda. Pengadilan dari negara home bisa

27 Walter Carlsnaes, Thomas Risse, \& Beth A. Simmons. Handbook Hubungan Internasional (Bandung: Nusa Media, 2013) menjadikan Chevron memiliki kekuatan hukum untuk membalikkan tuntutan.

Chevron punya kekuatan yang relatif dalam melobi gugatan tersebut. Chevron menyerang kembali dengan bukti kuat mengenai kecurangan dalam peradilan meliputi korupsi dan pemalsuan data. Ted Nace juga menjelaskan perusahaan memiliki kemampuan untuk mengontrol media. Hak tersebut dilakukan Chevron untuk mengontrol pemberitaan melalui video yang diunggah bahwa tokoh masyarakat di Amazon melanggar hukum dalam kasus ini. Hasil laboratorium dijadikan alat untuk melobi putusan bahwa Chevron tidak terlibat apapun atas kerusakan yang dilakukan oleh Texpet. Terlebih lagi perjanjian Ekuador dan Texaco sebelumnya bahwa dengan biaya perbaikan yang sudah diberikan Texaco maka tidak akan lagi ada tanggung jawab di masa mendatang. Chevron menganggap bahwa sudah tidak ada lagi masalah dan Ekuador hanya ingin mendapatkan uang dari Chevron. Setelah hengkangnya Texaco di 1992, Petroecuador yang melanjutkan mengeksploitasi sumber daya alam di wilayah tersebut. Hal tersebut dijadikan ketidakadilan jika tuntutan diberikan pada Chevron.

Melalui kasus tersebut, bagaimana masyarakat harus berpihak? Apakah negara yang memiliki kerugian akibat hadirnya korporasi ataukah korporasi yang dirugikan oleh tindakan korupsi dan politisasi dari negara? Dengan ini dapat dipelajari bahwa survei mengenai korporasi oleh business weeks bahwa kekuatan perusahaan multinasional dapat melebihi kekuatan negara. Chevron membuktikan mampu mengalahkan legitimasi hukum negara. ${ }^{28}$

Bukti selanjutnya yang menyatakan Chevron mampu menjadi aktor yang sangat kuat dengan pengajuan gugatan Chevron di Belanda tehadap Ekuador. Hasil keputusan pengadilan lokal Belanda adalah Ekuador harus membayar kepada Chevron sebesar 106 juta dolar. Walaupun Chevron tetap membayar kepada

${ }^{28}$ Nace, Ted, op. cit. 
pengadilan Ekuador (yang sebelumnya sempat tertahan oleh putusan banding pengadilan New York), tapi perusahaan ini mampu menuntut negara untuk juga membayar ganti rugi. ${ }^{29}$

Baik Texaco ataupun Chevron memang berkontribusi besar terhadap pencemaran air di Amazon melalui proses pengolahan minyak. Namun, kelemahan negara bisa dimanfaatkan perusahaan untuk menuntut balik melalui celahcelah hukum yang dapat digunakan Chevron.

\section{Kesimpulan}

Korporasi memiliki kekuatan politik dengan melakukan bargaining dengan masyarakat dan pemerintah di host country. Kekuatan politik tersebut berimplikasi kepada perubahan kebijakan negara. Quasi rights adalah persamaan hak yang dimiliki oleh perusahaan yang bergerak melampaui batas negara. Dengan hak istimewa tersebut menjadikan perusahaan memiliki hak hukum yang kuat dan setara dengan negara dan manusia. Serangan balik Chevron di Ekuador merupakan bukti bahwa ternyata hak konstitusi yang dimiliki perusahaan mampu merugikan negara. Ekuador mengalami kerusakan lingkungan dan juga kerugian karena harus membayar gugatan Chevron. Pengadilan internasional merupakan institusi yang mendukung bagaimana hak perusahaan tersebut bisa dimanfaatkan perusahaan multinasional untuk melawan negara melalui hukum dan politik.

\section{Referensi}

\section{Buku}

Adolf, H., 2009. Hukum Perdagangan Internasional. Jakarta: Rajawali Pers.

${ }^{29}$ Chang, Mayu. CORPWATCH (2014, 13 Oktober). Chevron Wins Ecuador Arbitration But Money May Go To Amazon Communities. Disandur dari http://www.corpwatch.org/article.php?id=15978
Amrullah, A., 2018. Perkembangan Kejahatan Korporasi. Jakarta: Prenamedia Group.

Bakry, U. S., 2015. Metode Penelitian Hubungan Internasional. Yogyakarta: Pustaka Pelajar.

Christoph Dörrenbächer \& Mike Geppert, 2011. Politics and Power in the Multinational Corporation. Cambridge: Cambridge University Press.

Don Mayer \& Ruth Jebe, 2010. The Legal and Ethical Environment for Multinational Corporations. In: Good Business. s.1.:Routledge, pp. 159-171.

Gilpin, R., 2001. Global Political Economy. New Jersey: Princeton University Press.

Nace, T., 2003. Gangs of America, The Rise of Corporate Power and The Disabling of Democracy. Berkeley: s.n.

Walter Carlsnaes, Thomas Risse, \& Beth A. Simmons, 2013. Handbook Hubungan Internasional. Bandung: Nusa Media.

\section{Jurnal \& Proceeding}

Black, E. C., 2004. Litigation As A Tool For Development: The Environment, Human Right, and The Case of Texaco in Ecuador. Journal of Public and International Affairs, pp. Vol. 15 pp 142-164.

Devita Prinanda \& Vinsensio Dugis, 2017. Winning Public Trust in Multi-Actor BargainingA Case Study of PT SMART Strategy in Facing Allegation of Environmental Destruction through RSPO. s.l., Atlantis Press.

Dewi Sinorita Setepu \& Silvia Dian Aggraini, 2007. Fenomena Korporasi dalam Konstelasi Internasional (Tinjauan Teoritis). Global \& Strategis, pp. 83-107. 
Latifah, E., 2015. Eksistensi Prinsip-Prinsip Keadilan dalam Sistem Hukum Perdagangan Internasional. Padjajaran Jurnal Ilmu Hukum, pp. 64-86.

Prigau, A., 2014. The Texaco-Chevron case in Ecuador: Law and justice in the age of Globalization. RCDA, p. Vol 5. No. 1.

\section{Laporan}

Chevron Press Release, 2000. Chevron and Texaco Aree to $\$ 100$ Billion Merger, San Fransisco: Chevron.

Chevron, 2011. Texaco Petrolium, Ecuador, and The Lawsuit Against Chevron, San Ramon: Chevron Corporation.

Ejolt, 2015. The Texaco-Chevron Case in Ecuador. s.l.:Environmental Justice Organisations, Liabilities, and Trade.

\section{Berita}

BBC Indonesia, 2011. Chevron Banding Putusan Denda US\$9,5 Miliar. Disandur dari https://www.bbc.com/indonesia/dunia/2011/03/1 10313_chevronecuador

BBC Indonesia, 2012. Chevron di Ekuador Diminta Bayar Denda. Disandur dari https://www.bbc.com/indonesia/dunia/2012/01/1 20104_ekuadorchevron

Detik Finance, 2011. Cemari Lingkungan, Chevron Didenda $R p 72$ Triliun. Disandur dari https://finance.detik.com/energi/d1571377/cemari-lingkungan-chevron-didendarp-72-triliun

Detik, 2012. Chevron di Ekuador Diminta Bayar Denda. Disandur dari https://news.detik.com/bbc-world/d1806795/chevron-di-ekuador-diminta-bayardenda

\section{Website}

Amazon Watch, 2015. Chevron's Secret Videos Show Company Technicians Finding and Mocking Extensive Oil Contamination in Ecuador Rainforest. [Online] Available at: http://amazonwatch.org/news/2015/0408chevrons-secret-videos-show-companytechnicians-finding-and-mocking-extensive-oilcontamination

Chang, M., 2014. Chevron Wins Ecuador Arbitration But Money May Go To Amazon Communities. [Online] Available at: http://www.corpwatch.org/article.php?id=15978 